\title{
Determinants of the Object of Protection of the Crime of Desecration of a Corpse and a Grave and Defamation of a Deceased Person ${ }^{2}$
}

Submitted: 24.10.2019. Accepted: 23.04.2021

\begin{abstract}
The article deals with the essence of the object of crime protection, as well as its genesis and conditions as exemplified by crimes against the honour of deceased people in selected countries. It has been hypothesised that factors such as religion, political system, historical and cultural conditions, geographical location, social system (social development) and the wealth of society influence the definition of the subject of the investigated crimes. The purpose of the work is also to indicate how the legislator creates a good legally protected in the event of a crime. On the one hand, these considerations have a purely linguistic and logical basis, i.e. an attempt is made to answer the question why we create names in relation to abstract objects, i.e. not having a real designation. The research hypothesis is that the object of protection remains only a linguistic entity created to justify the punishment of certain behaviours (and other needs), while it is possible to name the same value or phenomenon in different ways.
\end{abstract}

Keywords: legal good, criminal law, criminal protection of a human corpse.

$1 \quad$ Michał Tadeusz Najman, MA - University of Łódź (Poland); e-mail: ul0176207@edu.uni.lodz.pl; ORCID: 0000-0001-8207-8458.

2 The research project is not financed by any institution. 


\section{MICHAŁ TADEUSZ NAJMAN}

\section{Uwarunkowania przedmiotu ochrony przestępstwa zbezczeszczenia zwłok}

\section{Streszczenie}

W artykule poruszona została kwestia istoty przedmiotu ochrony, jej genezy i uwarunkowań na przykładzie przestępstw przeciwko czci osób zmarłych w wybranych krajach. Postawiono hipotezę, że czynniki takie jak religia, ustrój polityczny, uwarunkowania historyczno-kulturowe, położenie geograficzne, ustrój społeczny (rozwój społeczny) oraz zamożność społeczeństwa wpływają na określenie przedmiotu badanych przestępstw. Celem pracy jest również wskazanie, w jaki sposób ustawodawca kreuje dobro prawnie chronione na przez wprowadzenie przestępstwa do porządku prawnego. Rozważania te mają czysto językową i logiczną podstawę, tj. podjęto próbę odpowiedzi na pytanie, dlaczego tworzymy nazwy w odniesieniu do obiektów abstrakcyjnych, czyli nieposiadających rzeczywistego oznaczenia. Hipoteza badawcza jest taka, że przedmiotem ochrony pozostaje jedynie byt językowy stworzony w celu uzasadnienia karania pewnych zachowań (lub innych potrzeb), podczas gdy można tę samą wartość lub zjawisko nazywać na różne sposoby.

Słowa kluczowe: dobro prawne, prawo karne, prawnokarna ochrona zwłok ludzkich. 


\section{Introduction}

The issue of determining the conditioning of any social phenomenon, including law, is extremely complicated and difficult. It consists of many factors, including many of random nature, which cannot be grasped. Referring to the conditions of criminalisation of certain behaviours, one should first refer to the basis of their legitimacy, i.e. the object of protection, called a legal good ${ }^{3}$, which makes the behaviour perceived as deserving of condemnation. An attempt to answer this question was made by J. Makarewicz. ${ }^{4}$ He pointed to the development of crime as a derivative of the education of certain social institutions. However, this does not explain why we create these institutions, and in turn, why we consider them to be so important that we decide to limit our freedom in order to ensure their integrity. Let us leave this question to a philosophy that asks us about the meaning of human existence. For the purposes of further considerations, it seems sufficient to assume that a person develops certain institutions (language, law) for purely selfish reasons, where the institution is understood to limit the freedom of the individual in a certain way (negative concept of institution). So, a human being as an individual is guided by the pursuit of satisfying their needs. In order to achieve this, they create institutions, first society and then, as part of the community, rules of conduct (i.e. limit themselves) to meet their needs to a greater extent. The most extreme form of restriction is the criminal law response to violation of certain institutions. It seems that institutions that have developed earlier, i.e. more primitive, such as the prohibition of killing, the prohibition of harming the community, the prohibition of violating the integrity of the body of another human being, are now considered to be the unquestioned legal goods (life, health, social order). Other institutions, which are less primitive (e.g. property), although also developed at early stages of social development, are also widely accepted as legal goods now. However, there are secondary legal good things that can be argued in many ways. One of them is undoubtedly the legally protected good by criminalising corpse-defying behaviour.

\footnotetext{
3 S. Tarapata, Dobro prawne w strukturze przestępstwa. Analiza konstytucyjna i dogmatyczna, Warszawa 2016, p. 183.

$4 \quad$ J. Makarewicz, Wstęp do filozofii prawa karnego, Lublin 2009, p. 190 ff.
} 


\section{Religion}

Religion, like science today, once played a cognitive role in society. ${ }^{5}$ It explained some phenomena with the help of abstract concepts created only to facilitate understanding of the world. To some extent, it seems that religion influenced the formation of a social approach to human corpses. ${ }^{6}$ If in a given religion the existence of an alternative world of the dead was assumed, but existing outside the sphere of life of living people (as e.g. in Christian religions), then the described regulations are treated rather negligently. ${ }^{7}$ This is similar in denominations rejecting life after death. In turn, when a given religion assumes life after life, but in the world of living people (e.g. South Korea's shamanism or the indigenous Japanese Shinto religions), this results in a much more reliable regulation of a given issue, which is visible, for instance, in many Asian and South American regulations. ${ }^{8}$ In many countries, religion

5 S. Kamiński, Uwagi o języku teorii bytu, „Roczniki Filozoficzne” 1969, XVII, 1, p. 41; P.L. Berger, T. Luckmann, Społeczne tworzenie rzeczywistości, Warszawa 2010, pp. 51-52.

6 M. Eliade, Sacrum a profanum, Warszawa 2008, pp. 7-9; J. Le Goff, N. Truong, Historia ciała w średniowieczu, 2018, pp. 132-144.

7 For instance: Polish regulation (Article 262 of the Polish Criminal Code: $\S 1$. Anyone who profanes a corpse, human ashes or burial site is liable to a fine, the restriction of liberty or imprisonment for up to two years. § 2 . Anyone who robs a corpse, grave or another burial place is liable to imprisonment for between six months and eight years); source: https://supertrans2014.files.wordpress.com/2014/06/the-criminal-code.pdf (accessed: 30.06.2019); Chinese regulation (Article 302 of the Chinese Criminal Code: Whoever steals, insults corpses is to be sentenced to not more than three years of fixed-term imprisonment, criminal detention, or control); source: https://www. fmprc.gov.cn/ce/cgvienna/eng/dbtyw/jdwt/crimelaw/t209043.htm (accessed: 28.04.2019); Azerbaijan regulation (Article 245 of the Azerbaijan Criminal Code): Violation of a tomb or corpse - is punished by corrective works for the term up to two years or imprisonment for the term up to five years); source: https://www. legislationline.org/download/action/download/id/1658/file/4b3ff87c005675cfd74058077132.htm/preview (accessed: 30.06.2019); Cuban regulation (Article 188 of the Cuban Criminal Code: Whosoever, without complying with the legal formalities, performs an exhumation or has it performed or has a corpse or body remains be transported, shall be subject to a punishment of deprivation of freedom for a period of from three months to a year or a fine of one hundred to three hundred quotas); source: https://www.warnathgroup.com/wp-content/uploads/2015/03/Cuba-Penal-Code-Lawyers-Without-Borders-2009.pdf (accessed: 28.04.2019); Venezuelan regulation (Articles 172-173 of the Venezuelan Criminal Code: Article 172: Cualquiera que cometa actos de profanación en el cadáver o en las cenizas de una persona, y cualquiera que con un fin injurioso, o simplemente ilícito, sustrajere, fraudulentamente, el todo o parte de los despojos o restos mismos, o de alguna manera viole un túmulo o una cineraria, será castigado con prisión de seis meses a tres años. Article 173: Cualquiera que, fuera de los casos antes indicados, profanare, total o parcialmente el cadáver de alguna persona, lo exhumare, sustrajere o se apoderare de sus restos, será castigado con prisión de tres a quince meses. Si el hecho se ha cometido por el administrador o celador de un cementerio o lugar de sepulturas, o por persona a la cual se hubiere confiado la guarda del cadáver o de los restos, la pena se aumentará en una tercera parte en el primer caso, y en una cuarta parte en el segundo); source: https://wipolex.wipo.int/en/text/235415 (accessed: 30.06.2019); Brazilian regulation (Articles 211-212 of the Brazilian Criminal Code: Article 211: Destruir, subtrair ou ocultar cadáver ou parte dele: Pena - reclusão, de um a três anos, e multa. Vilipêndio a cadáver. Article 212: Vilipendiar cadáver ou suas cinzas: Pena - detenção, de um a três anos, e multa); source: https://wipolex.wipo.int/en/text/503824 (accessed: 28.04.2019).

8 For instance: Japanese regulation (Chapter XXIV. Crimes Related to Places of Worship and Graves: Article 188. (Profaning Places of Worship; Interference with Religious Service): (1) A person who in public profanes a shrine, temple, cemetery or any other place of worship shall be punished by imprisonment with or without 


\section{(sometimes called religious feelings) still remains the statutory object of protection for the crime of desecration of corpses. ${ }^{9}$}

work for not more-40-than 6 months or a fine of not more than 100,000 yen. (2) A person who interferes with a sermon, worship or a funeral service shall be punished by imprisonment with or without work for not more than 1 year or a fine of not more than 100,000 yen. Article 189. (Excavation of Graves): A person who excavates a grave shall be punished by imprisonment with work for not more than 2 years. Article 190. (Destruction of Corpses): A person who damages, abandons or unlawfully possesses a corpse, the ashes or hair of a dead person, or an object placed in a coffin shall be punished by imprisonment with work for not more than 3 years. Article 191. (Excavation of Graves and Damage of Corpses): A person who commits the crime proscribed under Article 189 and damages, abandons or unlawfully possesses a corpse, the ashes or hairs of a dead person, or an object placed in a coffin shall be punished by imprisonment with work for not less than 3 months but not more than 5 years. Article 192. (Secret Burial of Persons Dying from an Unnatural Death): A person who, without a postmortem examination, buries a person who died an unnatural death shall be punished by a fine of not more than 100,000 yen or a petty fine), source: http:// www.japaneselawtranslation.go.jp/law/detail/?id=1960\&vm=04\&re=02 (accessed: 30.06 .2019$) ;$ South Korean regulation (Chapter Xii Crimes Concerning Deceased Persons: Article 158. (Disturbing Funeral Service, etc.): A person who disturbs funeral rites, rituals, worship, or preaching, shall be punished by imprisonment for not more than three years or by a fine not exceeding five million won. Article 159. (Defiling Corpse, etc.): A person who defiles a corpse, remains, or the hair of the dead, shall be punished by imprisonment for not more than two years or by a fine not exceeding five million won. Article 160. (Excavation of Grave): A person who excavates a grave shall be punished by imprisonment for not more than five years. Article 161. (Exploring Tombs, etc.): (1) A person who damages, destroys, abandons, conceals or takes possession of a corpse, remains, or hair of the dead, or any Article deposited in a coffin, shall be punished by imprisonment for not more than seven years. (2) A person who commits the crime of the preceding paragraph by excavating a grave shall be punished by imprisonment for not more than ten years. Article 162. (Attempts): Attempts to commit the crimes provided in the preceding two Articles shall be punished. Article 163. (Obstruction of Inquest Over Unnatural Corpse): Any person who conceals or alters a corpse of a person who has died unnaturally, or a corpse suspicious of unnatural death, or obstructs the inquest over such corpse by other way, shall be punished by a fine not exceeding seven million won); source: http://www. moleg.go.kr/english/korLawEng?pstSeq=52670 (accessed: 28.04.2019); Uruguayan regulation (Article 307. Vilipendio de cadáveres o de sus cenizas. El que vilipendiare un cadáver, o sus cenizas, de cualquier manera, con palabras o con hechos, será castigado con seis meses de prisión a cuatro años de penitenciaría. Son circunstancias agravantes especiales de este delito, que el vilipendio se realice por exhumación, deformación, mutilación del cadáver, sustracción u ocultación del cadáver o de sus cenizas, y también por profanación sexual del cadáver. Article 308. Vilipendio de sepulcros, urnas y cosas destinadas al culto de los muertos. El que ejecutare actos de vilipendio, sobre una tumba, o sobre una urna, o sobre las cosas destinadas a su defensa u ornato, o al culto de los muertos, menoscabada la integridad, o la estética de los mismos, o mediante su violación, o con leyendas o inscripciones injuriosas, será castigado con seis meses de prisión a cinco años de penitenciaría. Article 309. Substracción de cadáveres o de restos humanos sin propósito de vilipendio. La sustracción, mutilación o exhumación de un cadáver, la exhumación o sustracción de sus cenizas, determinadas por móviles de piedad, de veneración, de amor, de investigación científica, serán castigadas con tres a dieciocho meses de prisión. La pena será elevada al doble, cuando tales hechos se efectuaran con fines de lucro); source: https://wipolex.wipo.int/en/text/196342 (accessed: 30.06.2019); Mexican regulation (Article 280. Se impondrá prisión de tres días a dos años o de 30 a 90 días multa: I. - Al que oculte, destruya o sepulte un cadáver o un feto humano, sin la orden de la autoridad que deba darla o sin los requisitos que exijan los Códigos Civil y Sanitario o leyes especiales; II. - Al que oculte, destruya, o sin la licencia correspondiente sepulte el cadáver de una persona, siempre que la muerte haya sido a consecuencia de golpes, heridas u otras lesiones, si el reo sabía esa circunstancia. En este caso no se aplicará sanción a los ascendientes o descendientes, cónyuge o hermanos del responsable del homicidio, y III. - Al que exhume un cadáver sin los requisitos legales o con violación de derechos. Art. 281. - Se impondrá de uno a cinco años de prisión: I. - Al que viole un túmulo, un sepulcro, una sepultura o féretro, y II. - Al que profane un cadáver o restos humanos con actos de vilipendio, mutilación, brutalidad o necrofilia. Si los actos de necrofilia consisten en la realización del coito, la pena de prisión será de cuatro a ocho años); source: https://wipolex.wipo. int/en/text/199697 (accessed: 28.04.2019).

9 See:CriminalCode of Austria-ChapterVIII,http://www.ilo.org/dyn/natlex/docs/ELECTRONIC/93674/109612/ F467747936/AUT93674\%20Ger.pdf (accessed: 28.04.2019); Criminal Code of Bahrain - Chapter Part 


\section{Political System}

There is no doubt that the legislator has the greatest impact on the formation of legal regulations. Another issue remains whether the established law is socially respected. For instance, customary law still plays a crucial role in Albania, and legal regulations remain secondary to it. ${ }^{10}$ However, the most visible role of the political system in the appearance of the legal regulation of the crime of desecrating a corpse is evident in totalitarian regimes. The diverse approach to the individual, according to which we adore some and repress others, also leaves our reflexes in the discussed regulation. ${ }^{11}$ In addition, man is to serve the state, not the other way around. First of all, the public interest is protected, not the private one. Another issue here is basing politics on nationalist beliefs. The protection of human corpses either becomes the protection of the interests of the state (e.g. the corpses of 'national heroes') or becomes unnecessary for the state, and ensuring the inviolability of physical human remains is limited to adopting casual, synthetic regulations that are treated as a violation of the common good.

\section{History}

The impact of historical considerations on the degree of the criminalisation of the crime of desecrating a corpse is, as it seems, significant. This is particularly evident in countries where crimes on humanity were committed in the form of genocide or others, aimed at the extermination of man. An example would be Rwanda, in which many criminal provisions refer to dealing with human corpses. ${ }^{12}$ This is

VIIM Chapter I, https://www.unodc.org/res/cld/document/bhr/1976/bahrain_penal_code_html/Bahrain_Penal_Code_1976.pdf (accessed: 28.04.2019); Criminal Code of Bangladesh - Chapter XV (https:// www.oecd.org/site/adboecdanti-corruptioninitiative/46812525.pdf (accessed: 28.04.2019); Criminal Code of Botswana - Part III, https://www.wipo.int/edocs/lexdocs/laws/en/bw/bw012en.pdf (accessed: 28.04.2019); Criminal Code of India - C hapter XV, http://lawyerchandigarh.com/wp-content/uploads/ The-Indian-Penal-Code-1860.pdf (accessed : 28.04.2019); Criminal Code of Germany - Chapter XI, https://www.gesetze-im-internet.de/stgb/index.html (accessed: 28.04.2019); Criminal Code of Nikaragua - Chapter IV, https://wipolex.wipo.int/en/text/478153 (accessed: 28.04.2019); Criminal Code of Spain - Chapter IV, https://www.legislationline.org/documents/section/criminal-codes/country/2/Spain/ show (accessed: 28.04.2019), Criminal Code of Uganda - PART III Chapter XIII, https:/ulii.org/ug/ legislation/consolidated-act/120 (accessed: 28.04.2019).

10 R. Elsie, A Dictionary of Albanian Religion, Mythology and Folk Culture, New York 2001, pp. 34-45.

11 B. Zhao, Posthumous Reputation and Posthumous Privacy in China: The Dead, the Law, and Social Transition, "Brooklyn Journal of International Law" 2014, 39/1, pp. 303-308.

12 Articles 117, 118, 119, 146, 180, 264-272 of the Rwandan Criminal Code, https://sherloc.unodc.org/res/ cld/document/rwa/1999/penal-code-of-rwanda_html/Penal_Code_of_Rwanda.pdf (accessed: 30.06.2019). 
undoubtedly the aftermath of historical events that have been well established in the minds of witnesses and are inscribed in the dark list of the most hideous actions that man has committed. An interesting example can also be Cambodia, where the genocide experiences remain vivid. ${ }^{13}$ It seems that a huge number of victims affected the perception of human corpses. Everyone has a need for dignity, which is why modern law guarantees it. However, the lack of its legal guarantee meant that man became perceived as an impersonal tool, which in principle did not differ from inanimate objects. In Cambodian legislation, this is evident in the dignity of human corpses. ${ }^{14}$ Another example is the practice described by P. Lemaitre in the novel See You Up There. ${ }^{15}$ The events described in the piece of work by a Frenchman deal with the practice of digging the graves of soldiers killed in battles during the First World War (including the Battles of the Marne and of Arras) and selling some of the corpses as the allegedly identified corpses of their fallen families. It seems that this could also affect the dignity of the human body by the French legislator. ${ }^{16}$

\section{Culture}

Culture, understood as the tangible and intangible heritage of human activities, plays a profound role in shaping all social behaviour. Part of the cultural heritage is based on religion, including the one related to handling human corpses. ${ }^{17}$ The axiology of faith itself does not explicitly specify how to proceed by performing rituals. Their procedure is a product of human thought and material activity. ${ }^{18}$ Among the behaviours performed on the corpse, it is worth paying attention to the type of burial, funeral customs, approach to death and the past in general. The manner of burial of the deceased, which is popularised in a given society, determines the regulation of the last service. The complexity of the ritual is determined by the degree of social development and the importance of religion in the community. In countries where faith plays a prominent role in society, a violation of burial

\footnotetext{
13 W. Tochman, Pianie kogutów, płacz psów, Kraków 2019, pp. 137-156.

14 http://sithi.org/admin/upload/law/Criminal_Code_Book_with_cover_Jan_2014.pdf (accessed: 30.06.2019).

15 P. Lemaitre, Do zobaczenia w zaświatach, Warszawa 2018.

16 French Codè Penal, https://www.legifrance.gouv.fr/affichCode.do?cidTexte=LEGITEXT000006070719 (accessed: 28.04.2019).

17 M. Kerrigan, Historia śmierci. Zwyczaje i rytuaty pogrzebowe od starożytności do czasów wspótczesnych, Warszawa 2009, pp. 9-15.

18 L. Kolankiewicz, Dziady: Teatr Święta Zmartych, Gdańsk, 1999, pp. 34-35.
} 
laws already results in criminal liability $\left(\mathrm{Mexico}^{19}\right)$. An extensive analysis of the impact of culture and its development on the perception of death was conducted by P. Ariès. Using many examples, the author shows how the topic of death changed its status from a social taboo to something that people have become accustomed to over the years ${ }^{20}$. It seems that a departure from attributing value to death as a mysterious and mystical phenomenon in its nature is desirable on the one hand, as it allows the individual to focus on the realisation of temporal goals, and thus guarantees social development. ${ }^{21}$ On the other hand, a devotional attitude to death is one of the characteristics exclusive to man. Abandoning this trait can, as already pointed out by A. Huxley ${ }^{22}$, lead to the dehumanisation of man. ${ }^{23}$ Such a degradation of the notion of death in the universal discourse also undoubtedly affects criminal law regulations penalising crimes against human corpses. Another sphere of cultural life that determines the subject of protection of the crime of desecration of corpses is related to the architectural order and spatial planning of cities. This is particularly evident in small as well as overcrowded countries. Where there is no place even for the living, it is difficult to look for the dead. It seems that this extends the tolerance limit to certain types of behaviour performed on corpses that in other countries could be considered as legally and socially unacceptable. This, however, may have a chilling effect in the form of common reasoning that since it is impossible to provide the deceased with a proper place on earth, they should be protected, including by means of criminal law, in an intensified manner. It is worth noting that the corpse can be used to create a work of $\operatorname{art}^{24}$, and even be a sculpture when properly prepared. ${ }^{25}$

\section{Science}

Science contributes to the desacralisation of death. ${ }^{26}$ Leaving this world ceases to be seen as the worst of all acceptable alternatives. Sometimes it is just the opposite. Death becomes the most desirable choice, e.g. in the case of euthanasia or abortion.

\footnotetext{
19 Art 188 of Criminal Code of Mexico, https://wipolex.wipo.int/en/text/199697 (accessed: 28.04.2019).

20 P. Ariès, Człowiek i śmierć, Warszawa 2011, p. 207.

21 E. Patrige, Posthumous Interests and Posthumous Respect, "Ethics" 1981, 91(2), p. 252.

22 A. Huxley, Nowy wspaniaty świat, Warszawa 2017.

23 J. Habermas, Przyszłość natury ludzkiej. Czy zmierzamy do eugeniki liberalnej? Warszawa 2003, p. 217.

24 http://www.czermna.pl/ (accessed: 30.08.2017).

25 http://www.krakow.po.gov.pl/decyzja-prokuratury-dot.-wystawy-the-human-body-exhibition.html (accessed: 30.08.2017).

26 P. Ariès, op. cit., p. 426.
} 
On the other hand, as P. Ariès writes, death is a momentary failure of science. ${ }^{27}$ So we treat death as an enemy who must be fought. Moreover, the best way to explain death is to thoroughly analyse its victims. Therefore, human corpses are becoming the subject of research, which further reduces the scope of their criminal law protection. Alternatives to the use of human corpses are also increasingly being sought. Disturbing is the recently advanced philosophical trend that man should serve the earth after death, and therefore a corpse should be used as fertilizer. ${ }^{28} \mathrm{On}$ the other hand, the development of science has contributed to the elimination of some formidable customs related to the use of human corpses. In the Polish lands, death was seen as something that scares away everything, including illness. Therefore, the teeth were treated by touching the finger of the deceased person. ${ }^{29}$ The development of science justified the inviolability of corpses in a different way than metaphysical. It has been shown that contact with them is associated with the risk of infecting many microorganisms.

\section{Geographical Location}

The geographical location of the countries concerned also has an impact on the shape of the legal system. It is obvious that in a double-inland country where there are no rivers, regulations such as maritime or inland navigation law are unnecessary. Similarly, the issue of criminal law regulations relating to human corpses in countries where there is no physical corpse because of even lack of enough space for living. The reason for their absence can be different, e.g. burning and scattering ashes, burial at sea, mass graves. As exemplified by regulations, it can be seen that in island countries (Sri Lanka ${ }^{30}$, Belize ${ }^{31}$ ), the regulations of the crime of desecration of corpses are casual and too general.

\footnotetext{
27 Ibidem, p. 586.

28 https://www.westernjournal.com/state-inches-closer-allowing-human-remains-garden-fertilizer/ (accessed: 30 June 2019).

29 A. Fischer, Zwyczaje pogrzebowe ludu polskiego, Lwów 1921, pp. 217-224.

30 Article 292 of the Criminal Code of Sri Lanka, http://www.commonlii.org/lk/legis/consol_act/pc25130. pdf (accessed: 28.04.2019).

31 Article 324 of the Criminal Code of Belize, http://www.ilo.org/dyn/natlex/docs/ELECTRONIC/68422/66703/ F1776464508/BLZ68422.pdf (accessed: 28.04.2019).
} 


\section{Social System (Social Development)}

$\mathrm{H}$. Arendt, in an attempt to define dignity, pointed out that her existence depends on her social need and her legal guarantee. ${ }^{32}$ The author's reasoning can also be extended to other social needs, in particular those whose immanent character has not yet been denotated by the legislator in a universally acceptable way, if at all possible. The basis for protecting human corpses is above all such a social need. It should be borne in mind, however, that people primarily strive to meet their needs. So as E. Partridge rightly noticed, the survivors protect their rights by ensuring respect for the dead because it guarantees them that their dignity will be treated with respect after their death and it ensures that life achievements will not be lost after death. $^{33}$

\section{Wealth of Society}

However, not only beliefs in a given society influence the described regulations. An example here may be economic issues and related systemic conditions. As a rule, the authority to take care of the body of the deceased remains, with slight administrative restrictions, at the discretion of the deceased person's relatives. Then, when defining the subject of protection, emphasis is put on protecting the private interest (e.g. the deceased persons themselves or loved ones). This is evident in the regulations of democratic and prosperous countries (e.g. France, Sweden, Japan). On the other hand, in the event that the deceased remains a burden for their loved ones, especially in financial terms, the subject of protection and at the same time the obligation to guarantee not only the deceased but also the local society the safety and respect for the fundamental rights of the individual passes to the state. Then the subject is more focused on protecting the public interest or public order. This is evident in developing and relatively poor countries (e.g. Angola, Poland, China).

\section{Conclusions}

Many factors influence the definition of the object of protection of the crime of desecration of corpses. This is not a primary crime resulting from universal moral or ethical principles common in all cultures. Many factors influence the degree of

32 J.D. Macready, Hannah Arendt and the Fragility of Human Dignity, Lexington Books, Lanham 2018, p. 11.

33 E. Partridge, op. cit., p. 256. 
detail in the regulation, as well as its reliability. The basic religion seems to be here. In many regulations, the crime of desecrating a corpse is still treated as a crime against religion or a derivative definition of this subject of protection (respect for the dead ${ }^{34}$, religious feelings ${ }^{35}$, memory of the dead ${ }^{36}$ ). In the early stages of social development, religion was the basic tool for explaining phenomena by means of abstract concepts. The development of science, although it also benefits from the multitude of functions of abstract concepts, has limited the role of beliefs as cognitive tools. Gradual secularisation, called the major reformation ${ }^{37}$ by E. van Gleder ${ }^{38}$, somehow activated the potential hidden in non-religious factors on the influence of corpse regulation. Some of them, which are rooted in religion, such as funeral customs or the implementation of certain religious practices into everyday life, seem to have played a significant role in the legislator's approach to criminalising behaviour against corpses. Law is a reaction to social needs. Undoubtedly, historical factors have another factor that specifically determines the shape of corpse regulation. The best example, it seems, is the Rwandan legislation - a country where racial hate speech problems were - and unfortunately remain - common, and in which memories of genocide remain alive in the mind to this day. A similar situation is in Cambodia. The view of such conductive scenes as the denial of the dignity of not only living people but also their corpses undoubtedly influenced the legislator's more reliable approach to this issue. The next factor that influenced the settlement of the crime of desecration of corpses seems to have been geographical location. In small countries, especially small and island ones, where there is a lack of space for cemeteries, and as a result of which the customs of giving corpses to the sea or burning them have developed, the detail of a given crime is low. More attention is paid to protecting the honour of the deceased person. All the indicated factors, although undoubtedly important, are, however, only an effect, and perhaps a determinant of social development and the resulting social need to treat deceased people with respect, even on an equal footing with living people. Once again it is

34 See: Algierian Criminal Code - Sectio II (https://wipolex.wipo.int/en/text/228301); Angolan Criminal Code - Sectio III (https://wipolex.wipo.int/en/text/490243), Brazilian Criminal Code - Title V; Spanish Criminal Code - Chapter IV; Cambodian Criminal Code - Chapter V (http://ngocedaw.org/wp-content/ uploads/2015/05/Criminal_Code_EN-KH_Jan_2014.pdf (accessed: 28.04.2019); Somalian Criminal Code - Chapter II (https://www.refworld.org/docid/4bc5906e2.html) (accessed: 28.04.2019).

35 See: Brazilian, Spanish, Ugandan Criminal Codes mentioned hereinbefore.

36 Lithuanian Criminal Code (Chapter XLV), http://www.uwm.edu.pl/kpkm/uploads/files/litewski-kodeks-karny.pdf (accessed: 28.04.2019).

37 Compared to the minor reformation that took place in the 16th century (E. van Gelder, The Two Reformations in the 16th Century: A Study of the Religious Aspects and Consequences of Renaissance and Humanism, "Revue belge de Philologie et d'Histoire" 1963, 41(4), pp. 1304-1305.

38 E. van Gelder, op. cit., p. 1304. 
appropriate to quote E. Partridge's words, which I consider to be the essence of the protection of the rights of the deceased, that the living protect their rights by ensuring respect for the dead because it guarantees them that their dignity will be treated with respect after their death, and thus, a guarantee of the fact that what we achieved during life will not be destroyed after our death. In this article, only several difficulties related to the exegesis of the subject of protection of the object of the crime of desecration of corpses were outlined. It should be remembered that the law is a social phenomenon and its shape depends on numerous factors, the number of which cannot be determined even approximately.

\section{Bibliography}

Ariès P., Człowiek i śmierć, Warszawa 2011.

Berger P.L., Luckmann T., Spoteczne tworzenie rzeczywistości, Warszawa 2010.

Eliade M., Sacrum a profanum, Warszawa 2008.

Elsie R., A Dictionary of Albanian Religion, Mythology and Folk Culture, New York 2001.

Fischer A., Zwyczaje pogrzebowe ludu polskiego, Lwów 1921.

Gelder E. van, The Two Reformations in the 16th Century: A Study of the Religious Aspects and Consequences of Renaissance and Humanism, "Revue belge de Philologie et d'Histoire" 1963, 41(4), pp. 1304-1307.

Habermas J., Przyszłość natury ludzkiej. Czy zmierzamy do eugeniki liberalnej? Warszawa 2003. Huxley A., Nowy wspaniały świat, Warszawa 2017.

Kamiński S., Uwagi o języku teorii bytu, „Roczniki Filozoficzne” 1969, XVII, 01, pp. 41-54.

Kerrigan M., Historia śmierci. Zwyczaje i rytuaty pogrzebowe od starożytności do czasów wspótczesnych, Warszawa 2009.

Kolankiewicz L., Dziady: Teatr Święta Zmartych, Gdańsk 1999.

Lemaitre P., Do zobaczenia w zaświatach, Warszawa 2018.

Le Goff J., Truong N., Historia ciała w średniowieczu, Warszawa 2018.

Macready J.D., Hannah Arendt and the fragility of human dignity, Lanham 2018.

Makarewicz J., Wstęp do filozofii prawa karnego, Lublin 2009.

Partridge E., Posthumous Interests and Posthumous Respect, "Ethics" 1981, 91(2), pp. 243-264.

Tarapata S. Dobro prawne w strukturze przestępstwa. Analiza konstytucyjna i dogmatyczna, Warszawa 2016.

Tochman W., Pianie kogutów, płacz psów, Kraków 2019.

Zhao B., Posthumous Reputation and Posthumous Privacy in China: The Dead, the Law, and Social Transition, "Brooklyn Journal of International Law" 2014, 39/1, pp. 268-352.

\section{Legal acts}

Criminal Code of Brazil, https://wipolex.wipo.int/en/text/503824 (accessed: 28.04.2019). Criminal Code of Algieria, https://wipolex.wipo.int/en/text/228301 (accessed: 28.04.2019). 
Criminal Code of Angola, https://wipolex.wipo.int/en/text/490243 (accessed: 28.04.2019). Criminal Code of Austria, http:/www.ilo.org/dyn/natlex/docs/ELECTRONIC/93674/109612/ F467747936/AUT93674\%20Ger.pdf (accessed: 28.04.2019).

Criminal Code of Azerbaijan, https://www.legislationline.org/download/action/download/id/1658/file/4b3ff87c005675cfd74058077132.htm/preview (accessed: 30.06 2019). Criminal Code of Bahrain, https://www.unodc.org/res/cld/document/bhr/1976/bahrain_penal_code_html/Bahrain_Penal_Code_1976.pdf (accessed: 28.04.2019).

Criminal Code of Bangladesh, https://www.oecd.org/site/adboecdanti-corruptioninitiative/46812525.pdf (accessed: 28.04.2019).

Criminal Code of Belize, http://www.ilo.org/dyn/natlex/docs/ELECTRONIC/68422/66703/ F1776464508/BLZ68422.pdf (accessed: 28.04.2019).

Criminal Code of Botswana, https://www.wipo.int/edocs/lexdocs/laws/en/bw/bw012en. pdf (accessed: 28.04.2019).

Criminal Code of Cambodia, http://ngocedaw.org/wp-content/uploads/2015/05/Criminal_Code_EN-KH_Jan_2014.pdf (accessed: 28.04.2019).

Criminal Code of China, https://www.fmprc.gov.cn/ce/cgvienna/eng/dbtyw/jdwt/ crimelaw/t209043.htm (accessed: 28.04.2019).

Criminal Code of Cuba, https://www.warnathgroup.com/wp-content/uploads/2015/03/ Cuba-Penal-Code-Lawyers-Without-Borders-2009.pdf (accessed: 28.04.2019).

Criminal Code of Germany, https://www.gesetze-im-internet.de/stgb/index.html (accessed: 28.04.2019).

Criminal Code of India, http://lawyerchandigarh.com/wp-content/uploads/The-Indian-Penal-Code-1860.pdf (accessed: 28.04.2019).

Criminal Code of Japan http://www.japaneselawtranslation.go.jp/law/detail/?i$\mathrm{d}=1960 \& \mathrm{vm}=04 \& \mathrm{re}=02$ (accessed: 30.06 .2019 ).

Criminal Code of Lithuania, (http://www.uwm.edu.pl/kpkm/uploads/files/litewski-kodeks-karny.pdf (accessed: 28.04.2019).

Criminal Code of Mexico, https://wipolex.wipo.int/en/text/199697 (accessed : 28.04.2019).

Criminal Code of Nikaragua, https://wipolex.wipo.int/en/text/478153 (accessed: 28.04.2019).

Criminal Code of Poland, https://supertrans2014.files.wordpress.com/2014/06/the-criminal-code.pdf (accessed: 28.04.2019).

Criminal Code of Somalia, https://www.refworld.org/docid/4bc5906e2.html (accessed: : 29.04.2019).

Criminal Code of South Korea, http://www.moleg.go.kr/english/korLawEng?pstSeq $=52670$ (accessed: 28.04.2019).

Criminal Code of Spain, https://www.legislationline.org/documents/section/criminal-codes/country/2/Spain/show (accessed: 28.04.2019).

Criminal Code of Sri Lanka, http://www.commonlii.org/lk/legis/consol_act/pc25130. pdf (accessed: 28.04.2019).

Criminal Code of Uganda, https://ulii.org/ug/legislation/consolidated-act/120 (accessed: 28.04.2019). 
Criminal Code of Uruguay, https://wipolex.wipo.int/en/text/196342 (accessed: 30.06.2019). Criminal Code of Venezuela , https:/wipolex.wipo.int/en/text/235415 (accessed:30.06.2019). French Codè Penal, https://www.legifrance.gouv.fr/affichCode.do?cidTexte=LEGITEXT000006070719 (accessed: : 28.04.2019).

Criminal Code of Rwanda, https://sherloc.unodc.org/res/cld/document/rwa/1999/ penal-code-of-rwanda_html/Penal_Code_of_Rwanda.pdf (accessed: 30.06.2019).

\section{Websites}

http://sithi.org/admin/upload/law/Criminal_Code_Book_with_cover_Jan_2014.pdf (accessed: 30.06.2019).

http://www.czermna.pl/ (accessed: 30.08.2017).

http://www.krakow.po.gov.pl/decyzja-prokuratury-dot.-wystawy-the-human-body-exhibition.html (accessed: 30.08.2017).

https://www.westernjournal.com/state-inches-closer-allowing-human-remains-garden-fertilizer/ (accessed: 30.06.2019). 